УДК $376-056.2$ : 373.3

DOI: $10.15330 /$ esu. 1.171-179

\section{Світлана Чупахіна,}

кандидат педагогічних наук, доцент, ДВНЗ "Прикарпатський національний університет імені Василя Стефаника" (м. Івано-Франківськ, Україна)

Svitlana Chupakhina, Candidate of pedagogical sciences (PhD), Associate Professor, Vasyl Stefanyk Precarpathian National university (Ivano-Frankivsk, Ukraine) cvitlana2706@gmail.com

\title{
МЕТОДИЧНІ ПІДХОДИ ДО ЗАСТОСУВАННЯ ЕЛЕКТРОННИХ ОСВІТНІХ РЕСУРСІВ В ІНКЛЮЗИВНОМУ НАВЧАННІ МОЛОДШИХ ШКОЛЯРІВ
}

\section{METHODICAL APPROACHES TO THE APPLICATION OF ELECTRONIC EDUCATIONAL RESOURCES IN INCLUSIVE TEACHING OF PRIMARY SCHOOL PUPILS}

У статті розглянуто особливості застосування електронних освітніх ресурсів в інклюзивному навчанні молодиих иколярів задля формувания в них умінь прачювати $з$ електронними освітніми ресурсами, ио сприяе розвитку інтелектуального $i$ творчого потенціалу, вмінню правильно використовувати інформаційні ресурси в різних сферах діяльності людини, водночас забезпечуе підготовку учнів до життя в умовах інформачійного суспільства загалом.

Задля реалізачії мети досліджения обгрунтусмо поняття "електрониі освітні ресурси". Зосереджено увагу на застосуванні комп'ютерно зорієнтованих методичних систем на різних етапах навчання дітей з особливими освітніми потребами в умовах інклюзивного середовица початкової иколи.

Доведено, ио застосування електронних освітніх ресурсів в інклюзивному навчанні важливо застосовувати в різних режимах роботи з урахуванням особливостей розвитку учнів під час: опитування, бесіди, обговорення процесу виконання завдання; пояснення нового матеріалу, наочної демонстрачії, виконания завдань, підведения підсумків уроку; самостійної навчальної діяльності (індивідуальна, парна, групова робота); контролі результатів навчання, тестуванні, коригуванні індивідуальної траєкторії; проектної роботі, під час вирімення проблемних завдань, виконання практичної чи лабораторної роботи, також у роботі з учнями з особливими освітніми потребами в умовах комплексної допомоги та співпрачі з сім'сю.

Ключові слова: інклюзивне навчання, інформатизація освіти, електронні освітні ресурси, діти з особливими освітніми потребами, комп'ютерно зоріситовані методичні системи, початкова икола, технологія мультимедіа, гіпермедіа, освітній прочес.

The article deals with the peculiarities of the usage of electronic educational resources in the inclusive education of primary school pupils in order to form in them the abilities to work with electronic educational resources, which promotes the development of intellectual and creative potential, the ability to properly use informational resources in various spheres of human activity, while ensuring the preparation of pupils for life in conditions of the al society as a whole.

For the purpose of the research goal, we justify the concept of "electronic educational resources". The focus is on the application of computer-based methodical systems at different stages of teaching children with special educational needs in an inclusive primary school environment.

It is justified that electronic learning tools has a number of advantages over traditional ones. Electronic learning tools enable you to combine the capabilities of computer technologies with traditional media, help to make the learning process entertaining, dynamic, unconventional, 
engaging, and engage pupils in the process of active collaboration. At the same time, the learning process becomes differentiated, individual and mobile, which provides a transition from an explanatory-illustrated way of learning to an active one.

It is proved that the usage of electronic educational resources in inclusive learning is important to apply in different modes of work, taking into account the peculiarities of pupils' development during: questioning, conversation, discussing the process of task fulfillment; explaining new material, visual demonstration, completing tasks, summarizing the lesson; independent educational activity (individual, paired, group work); control of training results, testing, adjustment of individual trajectory; project work, when solving problematic tasks, carrying out practical or laboratory work, also working with pupils with special educational needs in the context of comprehensive assistance and cooperation with the family.

Key words: inchusive learning, informatization of education, electronic educational resources, children with special educational needs, computer-oriented teaching systems, elementary school, multimedia technology, hypermedia, educational process.

Постанова проблеми. Активне впровадження інформаційних технологій в сучасну освіту вирішує низку проблем розвитку позитивної мотивації до навчання школярів, водночас відкриває нові можливості для управління навчальнопізнавальною діяльністю, підвищуе ефективність навчально-виховної роботи i забезпечує результативність процесу навчання загалом.

Враховуючи сучасні досліджень та можливості, електронні освітні ресурси сприяють раціональній організації пізнавальної діяльність учнів; створюють умови ефективнішого навчання; будують відкриту систему освіти, яка забезпечує індивідуалізацію навчання; допомагають залучити в процес активного навчання категорії дітей, що відрізняються здібностями та стилем навчання; звернутися до нових пізнавальних засобів; інтенсифікувати всі рівні освітнього процесу загалом [7].

Аналіз наукових досліджень і публікацій. Інформатизація освіти зосереджує увагу на застосуванні комп'ютерно зорієнтованих методичних систем на різних етапах навчання. В сучасних умовах ученими виділено три напрямки педагогічних завдань комп'ютеризації освіти (рис.1).

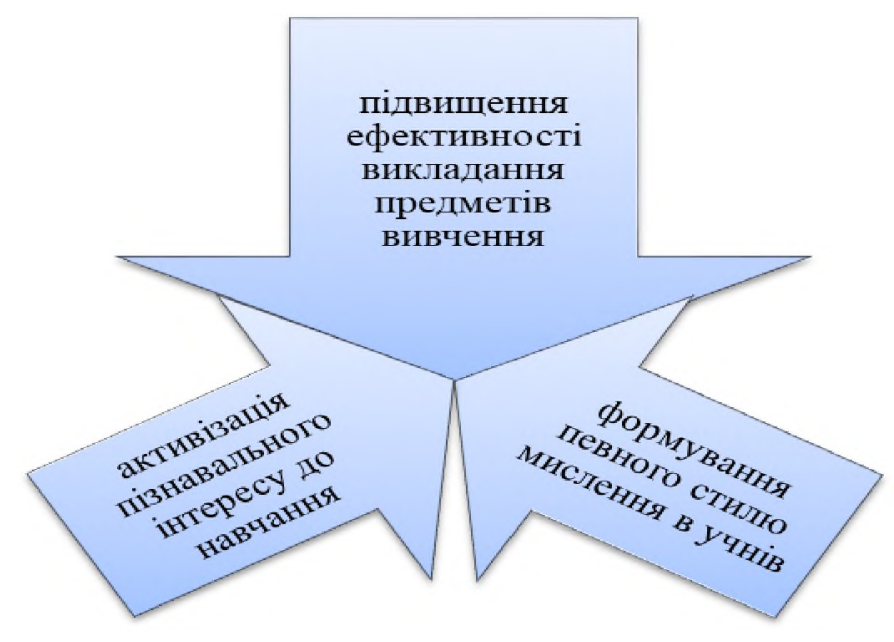

Складено автором за [5].

Рис. 1. Напрямки педагогічних завдань комп'ютеризації освіти

Успішне вирішення вищеозначених завдань здійснюється через використання електронних засобів навчання в освітньому процесі.

Формування в учнів умінь працювати 3 електронними освітніми ресурсами (ЕОР) сприяє розвитку інтелектуального і творчого потенціалу, вмінню правильно 
використовувати інформаційні ресурси в різних сферах діяльності людини, водночас забезпечує підготовку учнів до життя в умовах інформаційного суспільства загалом.

Сучасні дослідження щодо інформатизації навчального процесу (В Беспалько, В.Биков, В.Глушков, А.Єршов, М.Жалдак, Ю.Машбиць, М.Моїсеєв С. Пейперт (Seymour Papert), I.Роберт, Tim S. Roberts та ін.) засвідчують, що використання ЕОР у освітньому процесі підвищує ефективність навчання на всіх його рівнях.

Задля реалізації мети дослідження обгрунтуємо поняття "електронні освітні ресурси". Водночас в сучасній педагогіці не запропоновано однозначного визначення поняття й єдиної класифікації засобів навчання.

У визначенні понять, пов'язаних 3 електронними засобами навчання виокреслено низку синонімів, існує розбіжності і в їх трактуванні. У навчальнометодичних та наукових виданнях визначено такі електронні освітні ресурси як: комп'ютерні навчальні засоби, педагогічні програмні засоби, навчальні комп'ютерні програми тощо [7].

Інколи ЕОР ототожнюють 3 освітнім електронним виданням, під яким розуміють “електронне видання, яке містить систематизований матеріал 3 відповідної науково-практичної галузі знань, що забезпечує творче i активне оволодіння учнями знаннями, вміннями і навичками в означеній галузі" [3].

В наукових дослідженнях запропоновано наступне визначення електронних освітніх ресурсів - “програмні засоби навчального призначення, в яких відображено певну предметну область, реалізовано технологію іiі вивчення, забезпечено умови для реалізації певних видів навчальної діяльності" [2]. Інше обгрунтування ЕОР визначено як “засоби навчання, створені з використанням комп'ютерних інформаційних технологій” [7], а також ЕОР - “засоби, які працюють 3 використанням комп’ютерної та телекомунікаційної техніки та застосовуваних в навчанні школярів” $[7]$.

3 урахуванням науково-методичних досліджень, під електронними освітніми ресурсами будемо розуміти програмні засоби навчального призначення, які містять систематизований матеріал певної предметної області, що забезпечує творче й активне оволодіння учнями знаннями, вміннями i навичками (формує компетентності) в означеній галузі.

Щодо класифікації ЕОР, то сучасні дослідники розглядають 3 огляду на програмне, технічне забезпечення, психолого-педагогічні, ергономічні тощо особливості застосування, які характеризують означені ресурси з огляду на галузь дослідження.

Визначення та особливості використання ЕОР задля застосування в організації освітнього процесу запропоновано у наступних напрямках: подання навчальної інформації, водночас і для підготовки до уроку, задля створення електронних словників, дидактичних матеріалів, інтерактивних енциклопедій; здійснення пошуку необхідної інформації - аудіо-, відео-, графічної інформації, забезпечення доступу до неї та комплексне подання інформації в різноманітних формах; візуалізація досліджуваних об'єктів, явищ і процесів; організація різноманітних видів діяльності учнів із самостійного дослідження і аналізу інформації; контроль та перевірка знань учнів - тестування; управління освітнім процесом [8].

Відтак науковці, враховуючи функціональне призначення ЕОР, виділяє певні ïх типи (рис. 2) [4]. 


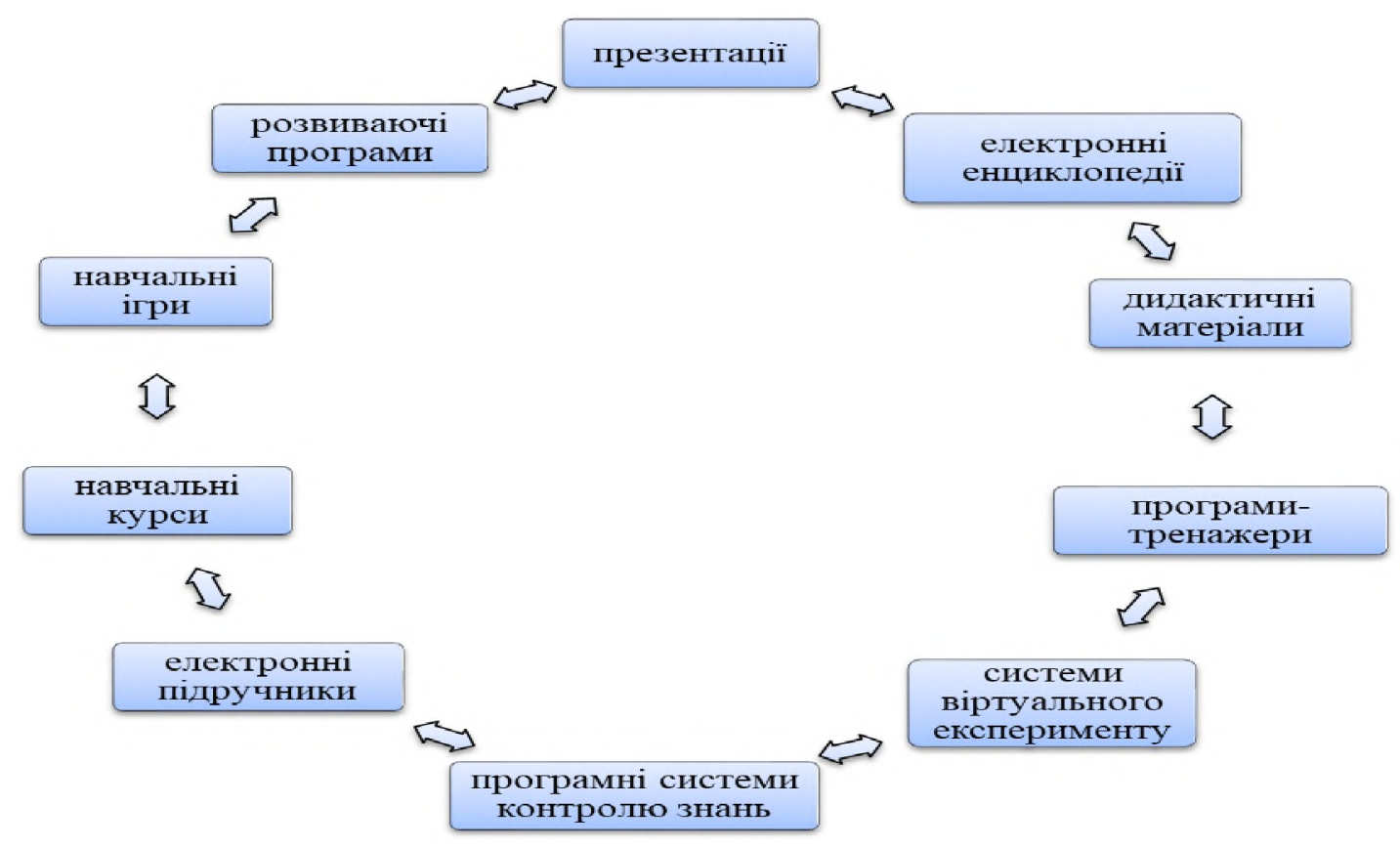

Складено автором за [4; 7].

Рис. 2. Типи ЕОР з урахуванням їх функціонального призначення

Мета дослідження полягає в грунтовному аналізі та обгрунтуванні методичних аспектів до застосування електронних освітніх ресурсів в інклюзивному навчанні молодших школярів в сучасних умовах

Виклад основного матеріалу дослідження. Поняття електронний та цифровий освітній ресурс використовуються як синоніми, однак у першому випадку закцентовано на функціонуванні його на базі електронно-обчислювальної машини (комп'ютера), а в другому - на базі програмування при оцифровуванні інформації. У започаткованому дослідженні будемо послуговуватись словосполученням ЕОР.

Грунтовний аналіз педагогічних ідей та напрацювань (Р. Вільямс, Б. Гершунський, В. Глушков, А. Довгялло, А. Сршов, Г. Клейман, Н. Краудер, К. Маклін, Ю. Машбиць, С. Пейперт, В. Скіннер та ін.) засвідчив, що електронні засоби навчання мають низку переваг над традиційними, це і зручність використання, можливість моделювання й прогнозування ситуацій, комплексний вплив на органи чуття, посилення аудіо-візуальних впливів, підвищення інформаційних та дослідницько-пошукових можливостей тощо. Електронні засоби навчання уможливлюють об'єднання можливостей комп'ютерних технологій 3 традиційними засобами надання інформації, допомагають зробити процес навчання видовищним, динамічним, нетрадиційним, цікавим, залучити учнів в процес активної співпраці. Водночас процес навчання стає диференційованим, індивідуальним й мобільним, відбувається перехід від пояснювально-ілюстрованого способу навчання до діяльнісного.

Опираючись на сучасні дослідження можемо укласти класифікацію EOP за їх методичним призначенням (рис.3).

Теоретичний аналіз наукових досліджень уможливлює структурування ЕОР, які відображаються в різних формах. У сучасній освіті їх різноманітність зростає прямо пропорційно розвитку сучасних електронних технологій.

Розробка та використання презентацій - найпоширеніший вид використання $\mathrm{EOP,} \mathrm{які} \mathrm{застосовуються} \mathrm{в} \mathrm{сучасній} \mathrm{початковій} \mathrm{школі} \mathrm{час} \mathrm{пояснення} \mathrm{матеріалу,}$ узагальненні вивченої теми, для розвитку просторового мислення учнів під час вивчення геометричного матеріалу тощо. 


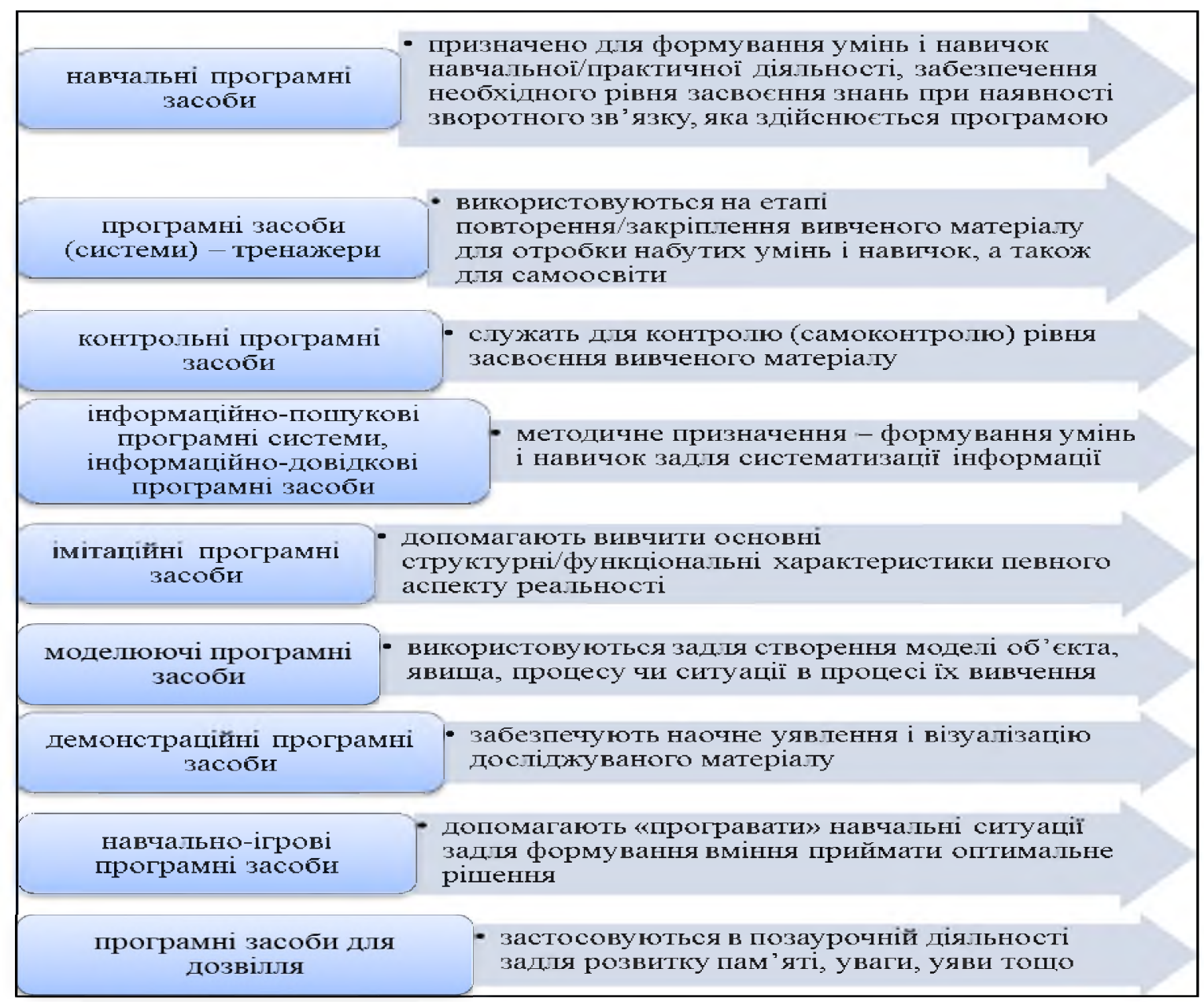

Складено автором за [10].

Рис. 3. Класифікація ЕОР методичного призначення

Окрім того, вчителі початкової школи використовується "Microsoft Word" для розробки текстових, водночас i дидактичних матеріалів, a "Microsoft Excel" використовується задля реалізації елементів автоматизації процесів управління навчанням, контролю та обліку результатів навчання, і для узагальнення освітньої діяльності. Найпоширеніші комплекти дидактичних матеріалів, представлено в електронному вигляді, і вони містять: “контрольно-оцінні матеріали, навчальні кросворди, таблиці, інструкції до виконання завдань, словники, тренажери, щоденники спостереження, методичні матеріали, новітні розробки, робочі зошити тощо" [4].

Проведений аналіз використання технології мультимедіа, гіпермедіа в освітньому процесі реалізовує певні дидактичні можливості IKT [10]: інтерактивність, зворотній зв'язок задля управління “подіями” на екрані, що переводить навчальний процес з пасивного в активний; візуалізацію та моделювання досліджуваних об'єктів чи процесів; автоматизацію контролю результатів навчання й управління навчальним процесом; автоматизацію пошуку навчального матеріалу тощо.

Інтерактивність ЕОР допомагає індивідуалізувати навчальний процес (скажімо, за наявності зворотного зв'язку та гіпертекстової розмітки навчального матеріалу в ЕОР) i надає учням можливість, 3 урахуванням індивідуальних особливостей кожного, “рівня підготовки, самостійно регулювати обсяг навчального матеріалу, темп вивчення, режим навчальної діяльності тощо. Вищеозначене особливо важливо для молодших школярів i учнів 3 особливими освітніми 
потребами в умовах інклюзивного навчання саме в початковій школі, оскільки прослідковуються відмінності в їх рівнях розвитку. Слід зауважити, що індивідуальна робота учня з ООП з ЕОР створює комфортні умови для роботи в зручному темпі й $з$ посильним для нього навантаженням, для багаторазового звернення до завдання чи проблеми.

Особливе значення в сучасних дослідженнях приділено інформаційній взаємодії при зворотного зв'язку: “вчитель - інтерактивний електронний освітній ресурс - здобувач освіти" в умовах зміни парадигми інформаційної взаємодії, коли всі (три) його учасники стають активними у спілкуванні. При означеній взаємодії, інформація, яка надходить від ЕОР до учня, у відповідь на його дії під час виконання завдання, уможливлює підвищення процесу отримання знань, оприлюднює результат навчальної діяльності, який пропонує поетапну оцінку i, при необхідності, забезпечує корекцію результатів навчальної діяльності. Відтак ЕОР виконує демонстраційну, навчальну, контролюючу, консультативну функцію й надає допомогу, пояснює, підказує хід виконання завдання, демонструє результат чи інший спосіб виконання навчального завдання.

Слід зауважити, що застосування ЕОР урізноманітнює урок, змістовно збагачує його; змінює темп уроку; посилює мотивацію навчання; урізноманітнює наочність; керує самостійною роботою учнів; індивідуалізує процес навчання; автоматизує оцінювання результатів навчальної діяльності учнів за допомогою тестування, що значно скорочує час оцінювання; автоматизує процес перевірки відповідей; зводить до мінімуму суб’єктну думку вчителя [10].

Застосування ЕОР, які зорієнтовано на інформаційну діяльність та інформаційну взаємодію, сприяє індивідуалізації навчання, самостійній навчальній діяльності, саморозвитку, підготовки кожного учня до самостійної діяльності в умовах інформаційного суспільства мережевої комунікації.

Методично здебільшого вчителі використовують ЕОР як допоміжний засіб під час підготовки до уроку (добір матеріалів в електронному вигляді та їх компонування задля використання на уроці; використання ресурсів Інтернет задля додаткової та довідкової інформації; розробка роздаткового матеріалу в електронному вигляді із наступною роздруківкою для кожного учня індивідуально тощо). Однак означене використання ресурсів не $є$ систематичним у професійній діяльності вчителів.

Методичні аспекти застосування ЕОР орієнтовано на індивідуальну самостійну роботу учнів, скажімо, під час використання електронних енциклопедій, довідників для розвитку уваги, пам'яті тощо. Іншим методичним напрямком використання ЕОР стає підготовка учнями презентацій, навчальних проектів тощо, для виконання домашньої роботи та самоосвіти.

Враховуючи на те, що вчитель на власний розсуд добирає матеріал для уроку, задає послідовність організації навчального процесу, відтак уможливлює оптимізацію навчального процесу, однак існуючі ЕОР не в повній мірі відповідають вимогам навчального процесу. Все це пов'язано з тим, що в процесі використанні EOP в у мовах інклюзивного навчання виникають певні труднощі, які пов'язано 3 віковими особливостями та можливостями молодших школярів. Спостерігається висока емоційність дітей, наслідком якої інколи стають образи чи агресивні стани, якщо вчитель пропонує роботу з ЕОР одному чи декільком учням. Вчителю важливо стежити за дотриманням санітарно-гігієнічних вимог, тривалості перебування учнів за комп'ютером і не допускати їх перевищення. Різна швидкість виконання учнями 
завдань в електронному вигляді ускладнює організацію інших видів діяльності на уроці. Уникнути означених проблем можливо за допомогою інтеграції застосування EOP та традиційних засобів навчання; використання групових норм організації роботи з ЕОР; організації застосування ЕОР для самостійної навчальної діяльності молодших школярів на уроці і в позаурочний час; усвідомлення й дотримання учнями необхідних обмежень у роботі з ЕОР тощо.

Водночас аналіз засвідчив, що використання ЕОР в навчальному процесі початкової школи не передбачає їх перевірку на педагогічно-ергономічну якість (Р. Вільямс, Б. Гершунський, В. Глушков, А. Довгялло, А. Сршов, Г. Клейман, Н. Краудер, К. Маклін, Ю. Машбиць, С. Пейперт, В. Скіннер та ін.), тобто експертизу: надійності функціонування ЕОР; інтерактивності взаємодії, відповідності вимогам UNESCO; візуалізацію поданих на екрані досліджуваних об'єктів чи процесів; автоматизацію контролю результатів навчання тощо [1; 9].

Відтак, на нашу думку, повноваження інтерактивної взаємодії з ЕОР дозволяє залучати учня з ООП не лише в навчальну діяльність, а й в навчально-ігрову та дозвільної діяльності 3 однолітками. Зворотнім зв'язком стає оцінювання діяльності,самостійне виявлення і виправлення помилок у процесі подання відповідей на прикінцевому етапі виконання завдань; корекція освітньої траєкторії учня; взаємодії під час створення та корекції екранних об'єктів і під час керування ними; створення оптимальної поетапності та послідовності засвоєння навчального матеріалу тощо.

Отож, можумо узагальнити, що завдання компетентного використання ЕОР в інклюзивному навчальному процесі актуальні як для вчителя початкової школи так i для учня з ООП. Велика кількість наявних у відкритому доступі ЕОР, різноманітних за призначенням, можливостями ЕОР визначає завдання ефективного їх використання в сучасному інклюзивному навчальному процес. Попередньо визначивши методичну доцільність їх застосування й виділивши педагогічне завдання задля їх використання учитель, стає експертом, самостіно оцінюючи знайдені матеріали та визначає їх місце на уроці. Вчитель може бути експертом лише щодо змістовно-методічного спрямування, може “враховувати індивідуальні особливості учнів, норми щодо використанню комп'ютерної техніки на уроках в тощо" [1], однак не може бути експертом щодо медико-психологічного, дизайнергономічного й технологічного напрямків ЕОР.

Висновки. Отож підсумовуючи вищеозначене можна зробити висновки, що застосування ЕОР в інклюзивному навчанні може бути організовано в різних режимах роботи залежно особливостей розвитку учнів під час: опитування, бесіди, обговорення процесу виконання завдання; пояснення нового матеріалу, наочної демонстрації, виконання завдань, підведення підсумків уроку; самостійної навчальної діяльності (індивідуальна, парна, групова робота); контролі результатів навчання, тестуванні, коригуванні індивідуальної траєкторії; проектної роботі, під час вирішення проблемних завдань, виконання практичної чи лабораторної роботи. Також ЕОР можна використовувати у роботі з учнями з ООП в домашніх умовах (за сприяння батьків чи старших родичів) задля: організації самостійної індивідуальної роботи; пошуку додаткової інформації (зокрема, через мережу Інтернет); підготовки творчих або дослідницьких, спільних з однокласниками, проектів; корекції прогалин у знаннях.

В процесі організації позаурочній діяльності ЕОР використовую під час організації роботи (ведення класних журналів, олімпіади, навчальні комп'ютерні розвиваючі програми - ігри, комплексної взасмодії різних фахівців тощо). 
Важливого значення набуває дослідження педагогічно-ергономічної якості ЕОР для використання в інклюзивному навчанні початкової школи на предмет виявлення: технологічної надійності функціонування; інтерактивності інформаційної взаємодії; відповідності вимогам UNESCO; візуалізації подання на екрані досліджуваних об'єктів чи процесів; автоматизації контролю результатів навчання тощо.

\section{Література}

1. Косик В. М. Проблеми безпечної роботи дітей в Інтернеті. Фільтрація несумісного 3 навчально-виховним процесом контенту. Комп 'ютер у школі та сім' ̈̈: Науково-методичний журнал, 2012. N 2. C. 33-35.

2. Кивлюк О. Створення комп'ютерно-ігрового середовища. Інформатика та інформаційні технологіï : Науково-методичний журнал. Київ : Педагогічна преса, 2012. С. 6-11.

3. Лапінський В. В. Дидактичні вимоги до комп'ютерно орієнтованих засобів навчання. Нові технології навчання : Наук.метод. зб. Київ : Наук.-метод. центр вищої освіти, 2004. Спецвипуск. $187 \mathrm{c}$.

4. Нікулочкіна О. В. Розвиток інформаційної компетентності вчителя початкових класів у системі післядипломної освіти: Автореф. дис. ... канд. пед. наук: 13.00.04; Класич. приват. ун-т. Запоріжжя, 2009. $20 \mathrm{c}$.

5. Основи стандартизаиії інформаџійно-комунікаційних компетентностей в системі освіти Украйни : Метод. реком. В. Ю. Биков, О. В. Білоус, Ю. М. Богачков та ін. Київ : Атіка, 2010. $88 \mathrm{c}$.

6. Очінювання якості програмних засобів навчального призначення для загальноосвітніх навчальних закладіє : Монографія. М. І. Жалдак, М. П. Шишкіна, В. В. Лапінський, К. І. Скрипка та ін.; За наук. ред. проф. М. І. Жалдака. Київ : Педагогічна думка, 2012. 132 с.

7. Сучасні інформаційні технології в науці та освіті : навчальний посібник. Вінниця : ВНТУ, $2018.161 \mathrm{c}$.

8. Як говорити з дітьми про безпеку спілкування он-лайн: [поради батькам] Ocвітні коментарі: Щорічник, 2011. № 2/3. $31 \mathrm{c}$.

9. The ICT Competency Framework for Teachers (ICT CFT). Published in 2018 by the United Nations Educational, Scientific and Cultural Organization, 7, place de Fontenoy, 75352 Paris 07 SP, France. $69 \mathrm{~s}$.

10. Chupakhina S. Methodological bases for digital competence formation of future teachers under conditions of inclusive education: Ukrainian content "Modern World tendencies in the development of science". volume 2, editor: Babych M.M., Published by Sciemcee Publishing. London, 2019, pp. $26-40$

\section{References}

1. Kosyk V. M. Problemy bezpechnoi roboty ditei v Interneti. Filtratsiia nesumisnoho z navchalnovykhovnym protsesom kontentu. Kompiuter u shkoli ta simi: Naukovo-metodychnyi zhurnal, 2012 N 2. S. 33-35.

2. Kyvliuk O. Stvorennia kompiuterno-ihrovoho seredovyshcha. Informatyka ta informatsiini tekhnolohii : Naukovo-metodychnyi zhurnal. Kyiv : Pedahohichna presa, 2012. S. 6-11.

3. Lapinskyi V. V. Dydaktychni vymohy do kompiuterno oriientovanykh zasobiv navchannia. Novi tekhnolohii navchannia : Nauk.metod. zb. Kyiv : Nauk.-metod. tsentr vyshchoi osvity, 2004. Spetsvypusk. $187 \mathrm{~s}$.

4. Nikulochkina O. V. Rozvytok informatsiinoi kompetentnosti vchytelia pochatkovykh klasiv u systemi pisliadyplomnoi osvity: Avtoref. dys. ... kand. ped. nauk: 13.00.04; Klasych. pryvat. un-t. Zaporizhzhia, 2009. $20 \mathrm{~s}$.

5. Osnovy standartyzatsii informatsiino-komunikatsiinykh kompetentnostei $\mathrm{v}$ systemi osvity Ukrainy : Metod. pekom. V. Yu. Bykov, O. V. Bilous, Yu. M. Bohachkov ta in. Kyiv : Atika, 2010. 88 s.

6. Otsiniuvannia yakosti prohramnykh zasobiv navchalnoho pryznachennia dlia zahalnoosvitnikh navchalnykh zakladiv : Monohrafiia. M. I. Zhaldak, M. P. Shyshkina, V. V. Lapinskyi, K. I. Skrypka ta in.; Za nauk. red. prof. M. I. Zhaldaka. Kyiv : Pedahohichna dumka, 2012. 132 s.

7. Suchasni informatsiini tekhnolohii v nautsi ta osviti : navchalnyi posibnyk. Vinnytsia : VNTU, 2018. $161 \mathrm{~s}$.

8. Iak hovoryty $\mathrm{z}$ ditmy pro bezpeku spilkuvannia on-lain: [porady batkam] Osvitni komentari: Shchorichnyk, 2011. № 2/3. $31 \mathrm{~s}$. 
9. The ICT Competency Framework for Teachers (ICT CFT). Published in 2018 by the United Nations Educational, Scientific and Cultural Organization, 7, place de Fontenoy, 75352 Paris 07 SP, France. $69 \mathrm{~s}$.

10. Chupakhina S. Methodological bases for digital competence formation of future teachers under conditions of inclusive education: Ukrainian content "Modern World tendencies in the development of science". volume 2, editor: Babych M.M., Published by Sciemcee Publishing. London, 2019, pp. $26-40$

Одержано статтю: 3.10 .2019

Прийнято до друку: 17.10.2019 